\section{Does Brand Awareness Influences \\ Purchase Intention? The Mediation Role of Brand Equity Dimensions}

\author{
Vitor Azzari ${ }^{1}$ \\ vitor.azzari@gmail.com | (100000-0002-1352-1660 \\ Anderson Pelissari ${ }^{2}$ \\ asoncinipelissari@gmail.com | (100000-0003-1567-8159
}

\begin{abstract}
This paper aims to identify the antecedent role of brand awareness in other dimensions of consumer-based brand equity (CBBE) and its impact on purchase intention. It is a quantitative study based on a survey conducted with 622 smartphone users. The theoretical hypothesis test was performed by structural equation modeling (PLS-SEM) and ordinary least squares (OLS) regression to analyze the mediation effect. The results demonstrate that brand awareness does not directly impact purchase intention. This effect is only observed when it is mediated by the three dimensions of CBBE perceived quality, brand associations, and brand loyalty. This investigation makes two major contributions. First, it demonstrates that knowing a brand is not enough to generate consumers' purchase intent. Second, it uses the mediating effect of the other dimensions of CBBE (associations, loyalty, and perceived quality) to demonstrate that brand awareness acts as a first step in building brand value for consumers.
\end{abstract}

\section{KEYWORDS}

Brand Awareness, Brand Equity, Purchase Intention, Smartphones

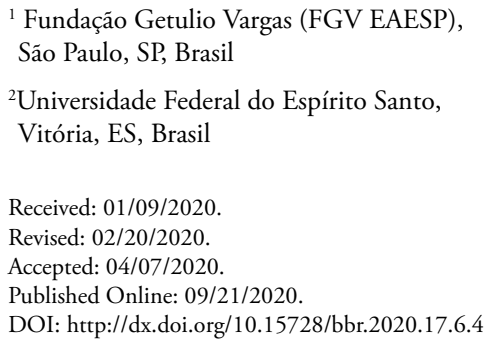




\section{INTRODUCTION}

Companies' dedication to build a strong and competitive brand in the perspective of consumers has become one of the key priority factors in the organizational environment (Christodoulides, Cadogan, \& Veloutsou, 2015). This is due to the important role of the brand in consumer decision making (Aaker, 1996), which makes brand management necessary to bring better performance to organizations and develop advantages over their competitors (Boicu, Cruz, \& Karamanos, 2015). The relevance of brand studies has brought the interest of the academic and professional community in the discussions about its value from the consumer's perspective. The so-called consumer-based brand equity (CBBE) has been studied and is defined as the set of assets that brand name and symbol hold in relation to a product (Keller, 1993; Aaker, 1996).

Due to the complexity and subjectivity surrounding the perception of brand equity, developing a CBBE conceptualization and measurement, with its formative dimensions and expected outcomes, is a challenging task (Christodoulides et al., 2015). Over the years, different dimensions of CBBE were identified and discussed (Christodoulides \& Chernatony, 2010; Veloutsou \& Guzman, 2017). Among the multiplicity of conceptualizations developed over the years, Aaker's model (1996) is highlighted as the most adopted one (Vieira, Sincorá, Pelissari, \& Carneiro, 2018). This author has identified that brand equity is comprised of brand loyalty, perceived quality, brand awareness and brand associations. Through these dimensions, brand equity would be able to deliver greater value to the company through increased prices and margins, competitive advantage, and greater consumer buying intent (Aaker, 1996).

However, as a multidimensional construct, it is important to analyze the effects and impacts of each of the dimensions of brand equity and how they relate to each other ( $\mathrm{Su}, 2016)$. Among the dimensions, brand awareness can be considered the most neglected and the one with greatest possibility of discussion and divergence of opinions (Romaniuk, Wight, \& Faulkner, 2017). This construct is conceptualized as the degree to which consumers are aware that a brand is part of a product category (Assael \& Day, 1968). Previous studies argued that brand awareness has a positive and direct impact on purchase intention (Keller, 1993; Wu \& Ho, 2014; Akkucuk \& Esmaeili, 2016). However, the emergence and growth of new brands in the recent years may show that simply being aware of the brand does not indicate a positive or negative perception. This might only be the first step towards generating attitudes and behaviors regarding the brand ( $\mathrm{Su}, 2016)$.

Therefore, brand awareness itself might not be enough to increase the consumers' purchase intent towards unknown brands. On the other hand, this construct may allow other positive consumer relationships with the brand to appear, such as perceived quality, brand loyalty, and brand associations (Grewal et al., 1998; Pappu, \& Quester, 2016; Foroudi et al., 2018) and thus generate the purchase intention. Therefore, this study aimed to analyze the antecedent role of brand awareness in the other dimensions of consumer-based brand equity and its impact on consumer purchase intention.

For this purpose, we chose to study smartphone brands. This choice is justified by the fact that this product is one of the most used today by the world population (Statista, 2019a). In addition, smartphones have an increasing importance in the global market and may have different characteristics, presenting a medium replacement cycle and low, medium, or high cost depending on product specifications. (Kim, Chun, \& Lee, 2014; Jyothsna, Mahalakshmi, \& Sandeep, 2016). It is noteworthy that among the top 10 brands in the world, six are linked to the technology segment and four develop smartphones (Interbrand, 2019). 
In order to fulfill the objective, we conducted a survey with 622 smartphone users. The data was analyzed using structural equation modeling (PLS-SEM) and ordinary least squares (OLS) regression by Macro Process. The results provide evidence showing that brand awareness exerts a predecessor role on other brand equity dimensions: brand loyalty, brand associations, and perceived quality. In turn, these dimensions mediate the relationship between brand awareness and purchase intention.

This study is relevant due to the divergent discussions concerning the relationship between the dimensions of CBBE. Over the years, it is common to identify previous research that allocates these four dimensions of CBBE linearly and independently by each other in consumer behavior (Cobb-Walgren, Ruble, \& Donthu, 1995; Hanzaee \& Asadollahi, 2012). However, there are still open spaces for discussion about the role of these dimensions and their relationships (Severi \& Ling, 2013). Moreover, it is intended to contribute to the business community by bringing a new perspective of brand awareness and showing that this variable can be used as a precursor of others to build a strong brand value from the consumer's perspective.

\section{CONSUMER-BASED BRAND EQUITY}

CBBE can be defined as the set of assets linked to the brand name and symbol that generates value for a product/service delivered to the consumer (Aaker, 1996), or as the differential effect of brand awareness on consumer response to brand marketing strategies (Keller, 1993). According to Aaker (1996), brand equity is a multidimensional construct composed of four dimensions, namely: brand awareness, perceived quality, brand associations, and brand loyalty.

In previous studies, CBBE indicated to have an important role for consumer's buying decisionmaking process, especially in the stages of searching for information and evaluating the alternatives (Jung \& Shen, 2011; Calvo-Porral et al., 2015; Akkucuk \& Esmaeili, 2016; Sharma et al., 2015). Brands with greater value decrease consumers' time and research cost, therefore, reducing the effort to make a good product choice and the risk (Aaker, 1996). Jyothsna, et al. (2016) suggest that brand equity plays an important role in shaping consumer buying intent, and it makes consumers have the brand as one of their first buying options. Calvo-Porral et al. (2015) suggest the need for managers to consider each of the dimensions of $\mathrm{CBBE}$ when developing the marketing strategies of organizations. On the other hand, if CBBE is considered a multidimensional concept (Aaker, 1996), it is necessary to analyze each of its dimensions described below.

Brand associations: an important ingredient of brand perception which occurs when the consumer thinks about a brand and develops some type of association linked to the memory that one has about it (Michel \& Donthu, 2014). These associations may include product attributes, lifestyle, personality, or symbols (Yoo \& Donthu, 2001). It is a type of mechanism that helps the consumer to remember the brand faster. Thus, the greater the experience with the brand, the greater the strength of the associations (Aaker, 1996).

Brand awareness: can be defined as the strength that the brand has in the consumer's mind (Aaker, 1996). Brand awareness involves two main elements: recall and recognition (Keller \& Lehmann, 2006). It is possible to make an analogy of this concept with advertising posters. If consumers' minds had multiple posters, each one referring to a brand, awareness would be based on the size of the posters. Thus, the larger the poster, the greater the awareness of that brand. Therefore, it refers to the consumer's ability to remember the brand as part of a certain product category (Huang \& Sarigölü, 2014; Da Costa, Patriotra, \& Angelo, 2017). 
BBR

17

672

Perceived quality: it is defined as the consumer's knowledge of the overall quality or superiority of a brand when comparing it with others (Aaker, 1996). This construct is considered high or low according to the intangible perception of the consumer (Yoo $\&$ Donthu, 2001). For Desai, Kalra and Murthi (2008), perceived quality refers to the consumer's knowledge about what he/ she sees and feels when looking and/or touching a product of a certain brand.

Brand loyalty: is one of CBBE's main assets. It is the measure of the link between the consumer and the brand, and the likelihood that the customer may change brands when the brand undergoes a price or product change (Aaker, 1996). This dimension is also defined as a positive consumer behavioral or emotional response to a brand (Pedeliento et al., 2016).

\section{THE RELATION BETWEEN BRAND AWARENESS, CBBE DIMENSIONS, AND PURCHASE INTENTION}

Several new brands in market are emerging and competing equally with already established brands (Pullig, Simmons, \& Netemeyer, 2006). In this situation, consumers' knowledge and awareness regarding the existence of the brand in a product category is not always a strong enough reason to directly affect purchase intention (Burnett \& Hutton, 2007). This may also be linked to technological advancement and high variations of prices and tools depending on the product model being offered. Therefore, it leads the consumer to pay more attention to these attributes than whether the brand is known or not (Wu \& Ho, 2014).

- H1: There is no direct positive relationship between brand awareness and purchase intention.

On the other hand, the fact that the brand is known opens a range of opportunities for consumers to develop positive behaviors and attitudes, like the other dimensions of CBBE: quality perception, brand associations, and brand loyalty (Grewal et al., 1998; Pappu, \& Quester, 2016; Foroudi et al., 2018).

When consumers are more aware of a brand, they are more confident and able to become loyal to that brand, whereas brands with a low level of awareness may find it harder to penetrate the market (Keller, 1993). Brand recognition is seen as a precursor to brand loyalty (Keller, 1993; Pappu, \& Quester, 2016). Authors who developed empirical studies indicated a positive relationship between brand awareness and brand loyalty in different industries, as cosmetics (Chinomona \& Maziriri, 2017), hospitality (Xu, Li, \& Zhou, 2015), and smartphones (Jing, Pitsaphol, \& Shabbir, 2014).

- Hza: There is a positive relationship between brand awareness and brand loyalty.

In turn, increased brand loyalty makes consumers more likely to buy the products, as well as it creates the ability to repurchase and increase positive word-of-mouth (Foroudi et al., 2018). In addition, they also create the possibility of increasing sales volume, attracting new consumers, and providing commercial leverage through distribution channels, which opt for the security of brands that have loyal customers (Ranjbariyan, Shahin, \& Jafari, 2012). Other empirical studies have also validated the positive impact of brand loyalty on consumer purchase intent, stating that loyal buyers tend to refer the brand to others and continue to buy the branded products even if the price is higher than competitors (Porral et al., 2015; Kim \& Kim, 2005; Akkucuk \& Esmaeili, 2016). 
- Hzb: There is a positive relationship between brand loyalty and purchase intention.

If consumers have heard of a brand at some point, and have had even indirect experiences with it, the possibilities of generating brand associations emerge (Chan, Boksem \& Smidts, 2018). Thus, after consumers are aware of the brand, some images and perceptions about the brand can rise in consumers' mind (Tariq, Abbas, Abrar, \& Iqbal, 2017). According to Shafiri (2014), brand awareness has a direct link with cognitive thinking and cognition, that can be considered dimensions of brand associations. Pitta \& Katsanis (1995) argue that brand awareness allows brand and product associations to be built and incorporated into consumer memory. Following this, there is evidence of the connection between awareness and brand associations in which the former precedes the latter (Keller, 1993; Dew \& Kwon, 2010; Foroudi et al., 2018).

- Hза: There is a positive relationship between brand awareness and brand associations.

In turn, brand associations may have a significant impact on consumer buying behavior (French $\&$ Smith, 2013), since associations generate value in different ways, such as helping to process and find information, establishing brand differentiation and positioning, and creating positive feelings about the brand (Dew \& Kwon, 2010; Jyothsna et al., 2016). Paço, Rodrigues, and Rodrigues (2015) argue that some specific positive dimensions of brand association, as utility and affect, impact the consumer purchase intention.

- H3b: There is a positive relationship between brand associations and purchase intention.

Regarding perceived quality, previous studies argue that consumers prefer to buy products from familiar and known brands, as they believe that the products will have higher quality, thus having lower risk in their purchase (Desai, Kalra \& Murthi, 2008; Das, 2015; Calvo-Porral \& Lévy-Mangin, 2017). Authors have tested the relationship between perceived quality and brand awareness in different contexts and identified that consumer perception of the brand improves as he/she already has some familiarity with it (Grewal et al., 1998; Chi, Yeh, \& Yang, 2009; Severi \& Ling, 2013).

- H4a: There is a positive relationship between brand awareness and perceived quality.

Quality perception enables consumers to reduce their uncertainty in decision making. The fact that one brand has higher quality than others makes the purchase risk lower and it increases the expectation of satisfaction when using the product (Calvo-Porral \& Lévy-Mangin, 2017). In addition, perceived quality also allows organizations to make use of premium pricing, that is, they apply a higher price in relation to the market without having a disadvantage in competing with competitors (Kim \& Kim, 2005). Also, higher perception of quality is related to a positive effect on brand value (Wang, 2017). Thus, it might improve consumers purchase intention (Petrick, 2004).

- H4b: There is a positive relationship between perceived quality and purchase intention.

Figure 1 shows the conceptual model developed based on the hypotheses presented. The following chapters present the methods and analysis to validate the model. 
BBR

17

674
H1

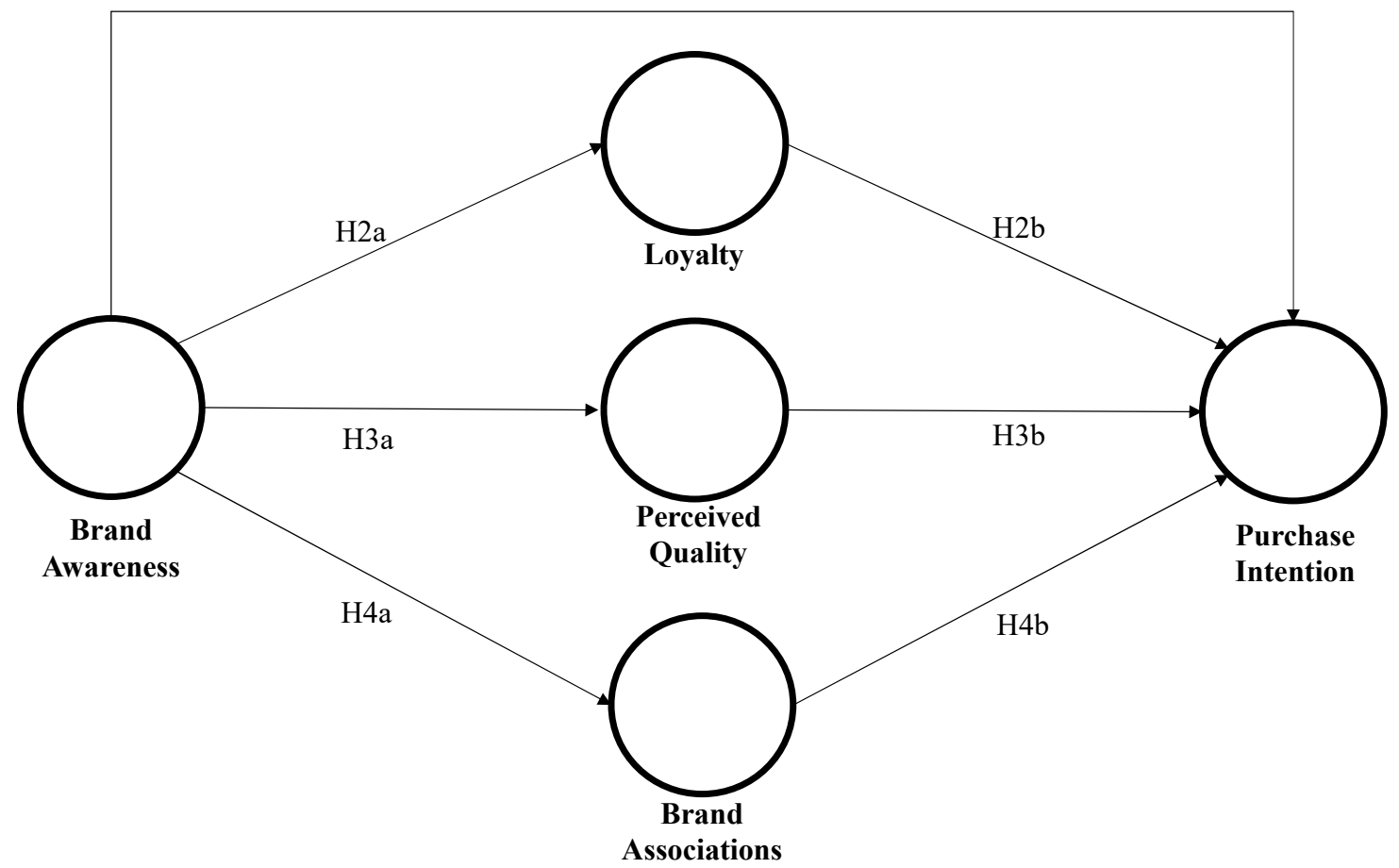

Figure 1. Model of tested hypotheses

Source: Authors' own elaboration

\section{METHODOLOGY}

\subsection{Data Collection and Sample}

Given the proposed hypotheses, the methodological strategy used was quantitative through a survey application. For this purpose, a questionnaire with closed-ended questions was used to identify the characteristics and opinions of the studied population. The sample chosen consisted of undergraduate students. Although this choice limits the development of generalized conclusions, the profile of college students matches with the age range of the main smartphone users (Statista, 2019b). In addition, previous CBBE studies have also used this type of sample (Yoo \& Donthu, 2001; Atilgan, Aksoy, \& Akinci, 2005; Hanzaee \& Assadollahi, 2012; Jyothsna et al., 2016).

The minimum sample size was defined according to Hair Jr. et al. (2017), which suggests verification through statistical power. The analysis was then aided by the $G$ * Power software, in which two parameters were used: the test power (Power $=1-\beta$ error prob. II) and the effect size $\left(\mathrm{f}^{2}\right)$. The calculation also considered the construct that had the largest number of predictors which is, in the case of the present model, the purchase intention with four pointed arrows (Hair Jr. et al., 2017). Thus, the software indicated that the use of a sample of 85 cases would already reach the statistical power of the test of $80.30 \%$. 
After the questionnaire was elaborated, it was sent to five academic professionals with experience in the area in order to acquire suggestions for improvement. Thus, based on their guidelines, some adjustments were made and after that, a pretest was applied with 28 students. The aim was to analyze the questionnaire applicability regarding the understanding of it and the way it was built, as well as to preliminary check the behavior of the relationships between the variables based on the small sample. The results obtained in the pretest were considered satisfactory, which allowed the field application of the survey.

The questionnaire was developed using the SurveyMonkey online tool and emailed to all students enrolled in university undergraduate courses. It is worth emphasizing that all questions were asked based on user experience regarding the brand of their current smartphone. The survey obtained a total of 720 responses. After collection, suspicious response patterns were found, characterized by Hair Jr. et al. (2017) as the phenomenon that occurs when the respondent marks the same scale item for a high proportion of questionnaire questions. In most cases, it is recommended to exclude responses that present this type of pattern (Hair Jr. et al., 2017). Therefore, 58 questionnaires were eliminated, resulting in 662 valid cases.

A considerable part of the sample (63\%) is composed of young people aged 16 to 22 years old, followed by respondents aged 23 to 29 years old (25\%). This data is coherent in relation to the population under analysis, which are undergraduate students. It can be observed that the age range of the sample is aligned with the object of study chosen for this research, considering that smartphones are mostly used by young people in their 20s (Statista, 2019b). Regarding the gender of the respondents, the distribution was roughly the same, however, females obtained a small majority of completed questionnaires representing $51 \%$ of the total sample $(n=340)$. All brands that composed the sample also maintained approximately the same distribution between genders.

Respondents were also asked about the smartphone brands used. The sample was concentrated in five main brands: Motorola (29\% of the total), Samsung (28\% of the total), Apple (16\% of the total), Asus (7\% of the total) and LG (6\% of the total). The remaining $13 \%$ of the sample use brands such as Lenovo, Xiaomi, Nokia and Sony. When asked which brands they would like to choose in their future smartphone purchase, the results showed that respondents focused on the Motorola (27\%), Apple (26\%) and Samsung (24\%) brands. It is noteworthy that 33\% of the sample indicated a preference for a different brand from the current one used in case of future purchase, which demonstrates that they are likely to change the brand of their smartphone.

\subsection{Measures}

The measurement used in this questionnaire was five-point Likert scale ranging from "strongly disagree" to "strongly agree". The operationalization of each variable is based on available instruments from prior relevant literature. The constructs perceived quality, brand loyalty, and brand associations were adapted from Yoo and Donthu (2001) that aimed to develop a multidimensional CBBE scale. Brand awareness operationalization was adapted from Yoo and Dontu (2001) and Shah (2012). And purchase intention was measured using an adapted scale from Grewal, Monroe, \& Krishnan (1998). The items of each variable were presented in Appendix A. 
BBR

17

676

\subsection{Data Analysis}

Data analysis was divided into two steps. The first was the application of the Structural Equation Modeling (PLS-SEM) technique through SmartPLS 3.0 to validate the measurement and structural model. This technique examines relationships using a set of methods to identify and analyze multiple dependency relationships between variables through a path diagram (Hair Jr. et al., 2017). The steps used to validate the measurement and structural model were based on Hair Jr. et al. (2017), which establish the criteria for determining internal consistency, convergent and discriminant validity, significance, and collinearity.

The second stage involved the analysis of mediations through the Macro Process model, which was employed according to Hayes (2018) parameters. The hypotheses developed in this study aimed to analyze the indirect path of relationships through mediations, and ordinary least squares (OLS) regression analysis, which is routinely used for this purposjustifying its application (Hayes, 2018). Moreover, through the Macro Process it is possible to analyze the whole model by the aggregate sum of its parts, unlike PLS-SEM, allowing better inferences for theory construction (Hayes, Montoya, \& Rockwood, 2017). For these reasons, it was considered relevant to use PLS-SEM for the validation of the measurement and structural model, and the use of OLS via Macro Process to analyze the total effect of mediation.

\section{RESULTS}

\subsection{Model Validation}

In order to evaluate the measurement model, we used a PLS Algorithm software tool named SmartPLS 3.0, it was applied to valid sample composed of 662 answers. When performing the calculations, the model converged with 07 interactions, a value lower than the recommended maximum of 300 interactions, thus meeting the convergence requirements of the algorithm (Hair Jr. et al., 2017).

The first criterion analyzed was internal consistency, which uses Cronbach's alpha values and composite reliability as parameters for validation. As recommended by Hair Jr. et al. (2017), all constructs had Cronbach's alpha above 0.708 and composite reliability below 0.95 . However, some indicators showed below-recommended external load values $(<0.708)$ and the indicator confidence values below the minimum $(<0.5)$. Therefore, the indicators correspondent to those values were excluded from the analysis, namely AW05, AS01 and AS02 (one indicator of the Brand Awareness construct and two of the Brand Associations construct). The exclusion of these indicators is justified by the positive impact on the construct validity by checking the stroke and composite reliability indices, as indicated by Hair Jr. et al. (2017). In addition, all constructs met the discriminant validity criteria as indicated in Fornell-Lacker's test results (Table 1).

After validating the measurement model with satisfactory quality levels, the next step was to analyze the structural model. This phase involves examining the model's predictive capabilities and the relationships between latent variables. The steps suggested by Hair Jr. et al. (2017) were used to evaluate the structural model. These steps consisted of performing the model collinearity tests, path coefficients significance, $\mathrm{R}^{2}$ value level, $f^{2}$ effect size, predictive relevance $\left(\mathrm{Q}^{2}\right)$ and $\mathrm{q}^{2}$ effect size, as well as the validation of the measurement model. All of the structural model tests were performed using SmartPLS 3.0 software. 
Table 1

Fornell-Lacker Criterion

\begin{tabular}{lccccc}
\hline Indicators & $\begin{array}{c}\text { Brand } \\
\text { Associations }\end{array}$ & $\begin{array}{c}\text { Brand } \\
\text { Awareness }\end{array}$ & Loyalty & $\begin{array}{c}\text { Perceived } \\
\text { Quality }\end{array}$ & $\begin{array}{c}\text { Purchase } \\
\text { Intention }\end{array}$ \\
\hline Brand Associations & $\mathbf{0 . 8 1 6}$ & & & & \\
Brand Awareness & 0.510 & $\mathbf{0 . 7 7 0}$ & & & \\
Loyalty & 0.370 & 0.417 & $\mathbf{0 . 8 1 3}$ & $\mathbf{0 . 8 4 6}$ & $\mathbf{0 . 8 5 2}$ \\
Perceived Quality & 0.424 & 0.481 & 0.542 & 0.682 & 0.657 \\
Purchase Intention & 0.530 & 0.446 & & & \\
\hline
\end{tabular}

Source: Authors' own elaboration

The collinearity analysis of the structural model was performed using the variance inflation factor (VIF) values. The endogenous latent variables of the model presented VIF values lower than 5.0 as indicated by Hair Jr. et al. (2017) as acceptable. This shows that respondents understood the constructs as phenomena different from each other.

The second stage of the analysis consisted of evaluating the significance and relevance of the path coefficients of the structural model. The relationships between Associations (AS), Loyalty (LO) and Perceived Quality (PQ) constructs with Purchase Intent (PI) construct showed a relevant level of significance (1\%). The relationship between Consciousness (AW) and Purchase Intention (PI) constructs was not significant, as presented in Table 2 . When analyzing the value of the path coefficient of this relationship, it has a negative value close to zero. On the other hand, the effect of brand awareness as antecedent of the variables: associations, perceived quality and loyalty was significant.

Table 2

Path coefficients relevance

\begin{tabular}{lccc}
\hline Path & Path Coefficients & t-value & p-value \\
\hline AS $\rightarrow$ PI & 0.238 & 7.920 & $0.000^{* * *}$ \\
AW $\rightarrow$ AS & 0.510 & 16.630 & $0.000^{* * *}$ \\
AW $\rightarrow$ LO & 0.417 & 13.283 & $0.000^{* * *}$ \\
AW $\rightarrow$ PQ & 0.481 & 14.168 & $0.000^{* * *}$ \\
AW $\rightarrow$ PI & -0.015 & 0.491 & 0.623 \\
LO $\rightarrow$ PI & 0.362 & 13.131 & $0.000^{* * *}$ \\
PQ $\rightarrow$ PI & 0.393 & 11.913 & $0.000^{* * *}$ \\
\hline
\end{tabular}

Note: $\mathrm{R}^{2}=0.625 ;{ }^{*}$ significant at $0.10,{ }^{* *}$ significant at $0.05,{ }^{* * *}$ significant at 0.01

Source: Authors' own elaboration

Following the validation steps of the structural model, the coefficient of determination $\left(\mathrm{R}^{2}\right)$ was evaluated. According to the criteria established by Hair Jr. et al. (2017) for research in the area of consumer behavior, the $\mathrm{R}^{2}$ found for the purchase intention construct $\left(\mathrm{R}^{2}=0.625\right)$ can be considered high. 
BBR

17

678

The fourth stage of model analysis sought to evaluate the effect size $f$, which measures the impact of the exogenous latent variable on the endogenous. In the analysis of the relationship of the constructs with the purchase intention variable, the results showed a small effect on brand associations $(f$ AS $\rightarrow \mathrm{PI}=0.104)$ and a moderate effect on perceived quality $(f \mathrm{PQ} \rightarrow \mathrm{PI}=0.251)$ and loyalty $(f \mathrm{LO} \rightarrow \mathrm{PI}=0.233)$. As expected, there was no effect on the brand awareness $(f$ $\mathrm{AW} \rightarrow \mathrm{PI}=0.000)$, since the relationship was not significant. By analyzing the relationship of brand awareness as predecessor to the other dimensions of brand equity, it can be observed that the effect based on the value of $f$ was large for brand associations $(f$ AW $\rightarrow$ AS $=0.352)$ and perceived quality $(f \mathrm{AW} \rightarrow \mathrm{PQ}=0.300)$, and it was moderated for loyalty $(f \mathrm{AW} \rightarrow \mathrm{LO}=0.211)$.

Finally, the fifth step was the analysis of the predictive relevance of the model $\left(Q^{2}\right)$, which was performed using the blindfolding procedure. This procedure is used to evaluate the ability of exogenous variables to predict the endogenous variable. The result obtained was a value above zero $\left(\mathrm{Q}^{2}=0.422\right)$ which supports the predictive relevance of the model to the endogenous construct. In addition, the relative impact of $\mathrm{q}^{2}$ of exogenous constructs on the endogenous construct was also evaluated. The constructs brand associations $\left(\mathrm{q}^{2}=0.163\right)$, perceived quality $\left(q^{2}=0.154\right)$, and loyalty $\left(q^{2}=0.108\right)$ indicated a moderate predictive relevance to purchase intention. Furthermore, as expected, the brand awareness $\left(q^{2}=0.000\right)$ did not point to direct predictive relevance to purchase intention.

Figure 2 shows the path coefficients and the significance of relationships between model variables. It also presents the indicators that were maintained after all validation criteria of the measurement model.

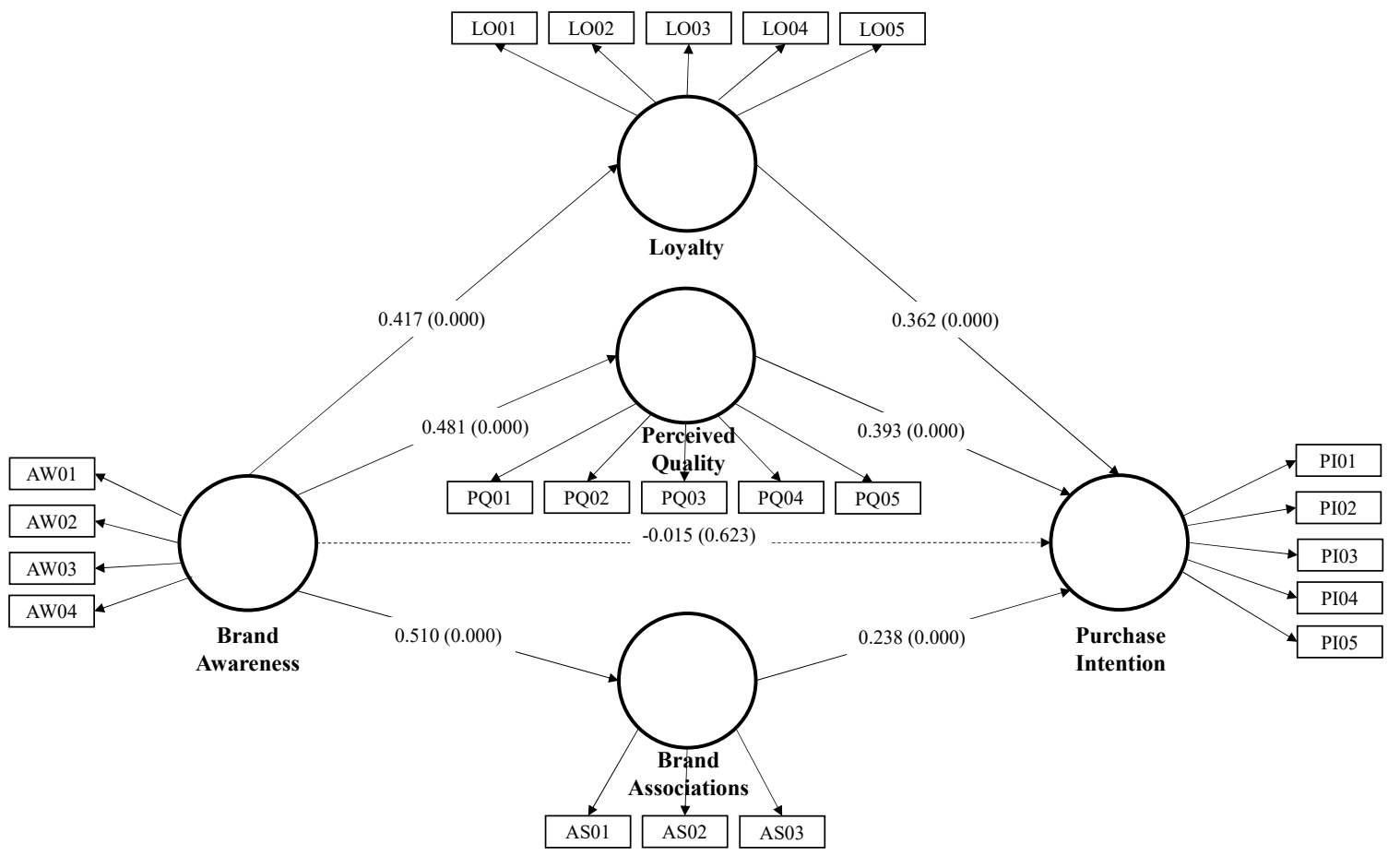

Figure 2. Structural Model (PLS-SEM)

Source: Authors' own elaboration 


\subsection{Multiple Mediation Analysis}

The mediating effects were also verified through the indirect relationship between brand awareness and purchase intention variables (Table 3). As previously described, the analysis of this step was done by regression analysis (OLS) of the Macro Process with 10.000 subsamples.

Table 3

Multiple Mediation Outcomes

\begin{tabular}{lccc}
\hline \multicolumn{4}{c}{ Direct effect of AW on PI: } \\
\hline \multicolumn{4}{c}{ Confidence interval } \\
Total & Effect & -0.1552 & 0.0090 \\
\hline \multicolumn{5}{c}{-0.0731} & Indirect effect of AW on PI: & \\
Total & Effect & Confidence interval \\
$P Q$ & 0.6323 & 0.5513 & 0.7106 \\
AS & 0.2560 & 0.1994 & 0.3168 \\
LO & 0.1848 & 0.1331 & 0.2369 \\
\hline
\end{tabular}

Source: Authors' own elaboration

The results demonstrate that the direct relationship between brand awareness and purchase intent is not statistically significant at the $95 \%$ confidence level. The indirect relationship of these variables, on the other hand, obtained statistical significance through the constructs perceived quality, brand associations, and brand loyalty. Thus, the existence of total mediation is proven, indicating that the effect of brand awareness on purchase intent (0.6323) is only significant and positive in indirect form, being mediated by the variables perceived quality, brand loyalty and associations with brand.

\section{DISCUSSION}

Understanding consumer behavior for a given product and brand represents a complex task that involves different variables. This study investigated the antecedent role of brand awareness in the other dimensions of CBBE and its impact on consumer purchase intention. The findings suggest that brand awareness does not directly impact purchase intention. On the other hand, the relation between these variables is indirectly mediated by CBBE dimensions: perceived quality, loyalty, and brand associations.

The findings demonstrate that there is a direct and significant relationship between CBBE dimensions (perceived quality, loyalty, and associations) and purchase intention, which resembles previous studies (Ranjbariyan et al., 2012; Calvo-Porral et al., 2015; Kim \& Kim, 2005; Jyothsna et al., 2016; Calvo-Porral \& Lévy-Mangin, 2017). On the other hand, the fact that brand awareness does not directly impact purchase intent differs from previous studies that demonstrated a direct positive relationship (Keller, 1993; Wu \& Ho, 2014; Akkucuk \& Esmaeili, 2016).

These findings may be connected to the fact that brand awareness is only the first step towards consumer perception of other aspects $(\mathrm{Su}, 2016)$. Thus, the fact that a brand is more famous and well-known to people may not be a strong enough reason to influence the decision-making of technology products such as smartphones, which are characterized by high price and tool variation (Wu \& Ho, 2014). In addition, the increased use of online medias to search information and 
reviews about brands and products, makes a shorter distance between less and better-known brands (Kudeshia \& Kumar, 2017).

On the other hand, brand awareness has an indirect impact on purchase intent, being mediated by perceived quality, brand associations and brand loyalty. Some brand equity models (e.g. CobbWalgren et al., 1995; Hanzaee \& Asadollahi, 2012) present the dimensions in a linearly and independently way, neglecting the relationship between these dimensions. The rationale behind the antecedent role of brand awareness is clear. The fact that a brand starts to be recognized by the consumer opens a range of possibilities such as the creation of brand associations, perception of quality, and loyalty (Pappu, \& Quester, 2016; Foroudi et al., 2018) and it can increase his willingness to buy a product of this brand.

Studies, such as Yoo and Donthu (2001), argue that brand awareness and associations should be combined according to their results. However, both variables have different concepts and different consumer behaviors emerge. Brand awareness acts as a variable that enables consumers to have associations with a brand, which would not be possible without this prior knowledge and familiarity (Foroudi et al., 2018).

In addition, the results also demonstrated a positive relationship between awareness and perceived quality, which is aligned with some previous studies (Grewal et al., 1998; Chi, Yeh, \& Yang, 2009; Severi \& Ling, 2013). This fact demonstrates that familiar and well-known brands generate a perception of quality in the consumers, who, in turn, choose to buy products of these brands because they believe they will have a lower risk associated with the purchase. The mediation role of brand loyalty is also aligned with previous studies (Keller, 1993; Pappu \& Quester, 2016). Brand awareness can contribute to greater market penetration and enable the generation of consumer loyalty.

Given the above, it is understood that brand awareness can still be considered a relevant variable for brand management, even it does not have a direct relationship with purchase intention. Furthermore, the antecedent role of brand awareness in the other dimensions of brand equity demonstrated in this paper, can generate discussions about previously developed models (e.g. Hanzaee \& Asadollahi, 2012) that adapt this variable in the same position as the others.

\subsection{Theoretical and Practical Implications}

From a theoretical point of view, the study contributed integrating the variables that together constitute brand equity with one of its main expected consequences. Some research found in the literature (Cobb-Walgren et al., 1995; Chen \& Chang, 2008) sought to analyze the relationship of brand equity and purchase intention using $\mathrm{CBBE}$ as just a single construct. This research provided an understanding of such variables through empirical study. In addition, as the main theoretical contribution, this study presents brand awareness as a predecessor of the other dimensions of CBBE. It is emphasized, according to the results, that this construct will only indirectly impact the intention to purchase, something that differs from previous studies (Keller, 1993; Malik, 2013; Wu \& Ho, 2014; Akkucuk \& Esmaeili, 2016) that did not control the effect of the other dimensions of CBBE, which may explain the divergence of results.

The practical contribution of the research is a greater understanding of consumer behavior and the factors that impact brand users' attitudes. The results allow companies to trace strategies developed for brands, besides the analysis of decision-making through metrics linked to the studied variables, such as brand awareness. 


\subsection{Limitations and Future Research}

This study has some limitations enabling challenges for future research. The first concerns the population chosen to be part of this study. Although the sample of students is consistent with the profile of most users of smartphones, the concentration of responses in this type of respondent does not allow the generalization of findings to people with other characteristics, which opens the possibility of future studies that broaden the population and the category of products explored.

Secondly, participants' responses were always based on the smartphone brands they currently used. Consequently, the questionnaire was answered based on the user's past and present experiences. Therefore, future surveys using less well-known predefined brands may contribute to the findings of this study.

Thirdly, brand awareness includes both recognition and recall (Keller, 1993). In our study, we used brand awareness as a general construct, not analyzing recall and recognition separately. Future research can include the test of these two dimensions on the model to understand how each one affects brand equity dimensions. Thus, it will be possible to verify if the strength of the relationship is higher in any of the two - recognition and recall.

\section{REFERENCES}

Aaker, D. A. (1996). Measuring brand equity across products and markets. California management review, 38(3), 102-120

Akkucuk, U., \& Esmaeili, J. (2016). The Impact of Brands on Consumer Buying Behavior. International Journal of Research in Business and Social Science (2147-4478), 5(4), 1-16.

Assael, H., \& Day, G. S. (1968). Attitudes and awareness as predictors of market share. Journal of Advertising Research, 8(4), 3-10.

Atilgan, E., Aksoy, S., \& Akinci, S. (2005). Determinants of the brand equity: A verification approach in the beverage industry in Turkey. Marketing intelligence \& planning, 23(3), 237-248.

Baker, M. J., \& Churchill Jr, G. A. (1977). The impact of physically attractive models on advertising evaluations. Journal of Marketing research, 14(4), 538-555.

Boicu, M. C., Cruz, A., \& Karamanos, A. (2015). The Influence of Online Reviews on Brand Equity and Purchase Intention of Smartphones and Tablets in Romania. Marketing and Consumer Behavior, 719-728.

Burnett, J., \& Hutton, R. B. (2007). New consumers need new brands. Journal of Product \& Brand Management, 16(5), 342-347.

Calvo-Porral, C., \& Lévy-Mangin, J. P. (2017). Store brands' purchase intention: Examining the role of perceived quality. European Research on Management and Business Economics, 23(2), 90-95.

Calvo-Porral, C., Martínez-Fernández, V. A., Juanatey-Boga, O., Mangín, L., \& Pierre, J. (2015). Measuring the influence of customer-based store brand equity in the purchase intention. Cuadernos de gestión, 15(1), 93-117.

Chan, H. Y., Boksem, M., \& Smidts, A. (2018). Neural profiling of brands: Mapping brand image in consumers' brains with visual templates. Journal of Marketing Research, 55(4), 600-615.

Chen, C. F., \& Chang, Y. Y. (2008). Airline brand equity, brand preference, and purchase intentionsThe moderating effects of switching costs. Journal of Air Transport Management, 14(1), 40-42. 
BBR

17

682
Chi, H. K., Yeh, H. R., \& Yang, Y. T. (2009). The impact of brand awareness on consumer purchase intention: The mediating effect of perceived quality and brand loyalty. The journal of international management studies, 4(1), 135-144.

Chinomona, R., \& Maziriri, E. T. (2017). The influence of brand awareness, brand association and product quality on brand loyalty and repurchase intention: a case of male consumers for cosmetic brands in South Africa. Journal of Business and Retail Management Research, 12(1).

Christodoulides, G., \& De Chernatony, L. (2010). Consumer-based brand equity conceptualization and measurement: A literature review. International journal of research in marketing, 52(1), 43-66.

Christodoulides, G., Cadogan, J. W., \& Veloutsou, C. (2015). Consumer-based brand equity measurement: lessons learned from an international study. International Marketing Review, 32(3/4), 307-328.

Cobb-Walgren, C. J., Ruble, C. A., \& Donthu, N. (1995). Brand equity, brand preference, and purchase intent. Journal of advertising, 24(3), 25-40.

da Costa, M. F., de Moraes Patriota, A. L., \& de Angelo, C. F. (2017). Propagandas de apelo emocional e utilitário: efeitos na atitude do consumidor e na percepção do brand equity de um celular Samsung. REGE-Revista de Gestão, 24(3), 268-280.

Das, G. (2015). Linkages between self-congruity, brand familiarity, perceived quality and purchase intention: A study of fashion retail brands. Journal of Global Fashion Marketing, 6(3), 180-193.

Dew, L., \& Kwon, W. (2010). Exploration of apparel brand knowledge brand awareness, brand association, and brand category structure. Clothing and Textiles Research Journal, 28(1), 3-18.

Desai, P. S., Kalra, A., \& Murthi, B. P. S. (2008). When old is gold: The role of business longevity in risky situations. Journal of Marketing, 72(1), 95-107.

Do Paço, A., Rodrigues, L., \& Rodrigues, R. G. (2015). Brand Image and Awareness in the Third Sector and their Influence on the Intention to Donate. Brazilian Business Review, 12(5), 97-117.

Foroudi, P., Jin, Z., Gupta, S., Foroudi, M. M., \& Kitchen, P. J. (2018). Perceptional components of brand equity: Configuring the Symmetrical and Asymmetrical Paths to brand loyalty and brand purchase intention. Journal of Business Research, 89, 462-474.

French, A., \& Smith, G. (2013). Measuring brand association strength: a consumer-based brand equity approach. European Journal of Marketing, 47(8), 1356-1367.

Grewal, D., Monroe, K. B., \& Krishnan, R. (1998). The effects of price-comparison advertising on buyers' perceptions of acquisition value, transaction value, and behavioral intentions. Journal of marketing, 62(2), 46-59.

Hair Jr, J. F., Hult, G. T. M., Ringle, C., \& Sarstedt, M. (2017). A primer on partial least squares structural equation modeling (PLS-SEM). Sage publications.

Hanzaee, K. H., \& Asadollahi, A. (2012). Investigating the effect of brand equity and brand preference on purchase intention. Research Journal of Applied Sciences, Engineering and Technology, 4(10), 1414-1423.

Hayes, A. F. (2018). Introduction to mediation, moderation, and conditional process analysis: A regressionbased approach. Guilford Publications.

Hayes, A. F., Montoya, A. K., \& Rockwood, N. J. (2017). The analysis of mechanisms and their contingencies: PROCESS versus structural equation modeling. Australasian Marketing Journal (AMJ), 25(1), 76-81. 
Huang, R., \& Sarigöllü, E. (2014). How brand awareness relates to market outcome, brand equity, and the marketing mix. Fashion Branding and Consumer Behaviors (pp. 113-132). Springer, New York, NY.

Interbrand (2019). Best Global Brands 2018 Rankings. Recuperado em 06 setembro, 2019 de https:// www.interbrand.com/best-brands/best-global-brands/2018/ranking/

Jing, Z., Pitsaphol, C., \& Shabbir, R. (2014). The relationship of brand equity dimensions: A case study of Samsung brand in Thailand. European Journal of Business and Management, 6(16), 182-189.

Jung, J., \& Shen, D. (2011). Brand equity of luxury fashion brands among Chinese and US young female consumers. Journal of East-West Business, 17(1), 48-69.

Jyothsna, M., Mahalakshmi, S., \& Sandeep, P. N. (2016). Role of Brand Equity and Brand Identity on Preferences of Smartphones among Students. Pacific Business Review International, 8(11), 44-53.

Keller, K. L. (1993). Conceptualizing, measuring, and managing customer-based brand equity. Journal of marketing, 57(1), 1-22.

Keller, K. L., \& Lehmann, D. R. (2006). Brands and branding: Research findings and future priorities. Marketing science, 25(6), 740-759.

Kim, D., Chun, H., \& Lee, H. (2014). Determining the factors that influence college students' adoption of smartphones. Journal of the Association for information Science and Technology, 65(3), 578-588.

Kim, H. B., \& Kim, W. G. (2005). The relationship between brand equity and firms' performance in luxury hotels and chain restaurants. Tourism management, 26(4), 549-560.

Kudeshia, C., \& Kumar, A. (2017). Social eWOM: does it affect the brand attitude and purchase intention of brands? Management Research Review.

Michel, G., \& Donthu, N. (2014). Why negative brand extension evaluations do not always negatively affect the brand: The role of central and peripheral brand associations. Journal of Business Research, 67(12), 2611-2619.

Pappu, R., \& Quester, P. G. (2016). How does brand innovativeness affect brand loyalty? European Journal of Marketing, 50(1/2), 2-28.

Pedeliento, G., Andreini, D., Bergamaschi, M., \& Salo, J. (2016). Brand and product attachment in an industrial context: The effects on brand loyalty. Industrial Marketing Management, 53, 194-206.

Petrick, J. F. (2004). The roles of quality, value, and satisfaction in predicting cruise passengers' behavioral intentions. Journal of travel research, 42(4), 397-407.

Pitta, D. A., \& Prevel Katsanis, L. (1995). Understanding brand equity for successful brand extension. Journal of consumer marketing, 12(4), 51-64.

Pullig, C., Simmons, C. J., \& Netemeyer, R. G. (2006). Brand dilution: when do new brands hurt existing brands? Journal of Marketing, 70(2), 52-66.

Ranjbariyan, B., Shahin, A., \& Jafari, S. (2012). Investigating the Influence of Customers' Feeling and Judgment on Their Loyalty with Emphasize on Brand Equity The Case of Isfahan Crystal and Glass Products. Australian Journal of Basic and Applied Sciences, 6(9), 517-524.

Romaniuk, J., Wight, S., \& Faulkner, M. (2017). Brand awareness: revisiting an old metric for a new world. Journal of Product \& Brand Management, 26(5), 469-476. 
BBR

17

684

Severi, E., \& Ling, K. C. (2013). The mediating effects of brand association, brand loyalty, brand image and perceived quality on brand equity. Asian Social Science, 9(3), 125.

Shah, R. (2012), A confirmatory factor analysis on brand equity in mobile handset market: SEM approach. Journal of Brand Management, 9(3), 40-54.

Sharma, V., Singh, R., \& Patel, G. N. (2015). Measuring the effect of brand equity on the consumers' purchase intention. International Journal of Services Technology and Management, 21(1-3), 98-110.

Statista (2019a). Number of smartphones sold to end users worldwide from 2007 to 2018. Recuperado em 06 maio, 2019 de https://www.statista.com/statistics/263437/global-smartphone-sales-toend-users-since-2007/.

Statista (2019b). Do you personally use a smartphone? - by age. Recuperado em 11 setembro, 2019 de https://www.statista.com/statistics/ 300402/smartphone-usage-in-the-uk-by-age/.

$\mathrm{Su}, \mathrm{J}$. (2016). Examining the relationships among the brand equity dimensions: empirical evidence from fast fashion. Asia Pacific Journal of Marketing and Logistics, 28(3), 464-480.

Tariq, M., Abbas, T., Abrar, M., \& Iqbal, A. (2017). EWOM and brand awareness impact on consumer purchase intention: mediating role of brand image. Pakistan Administrative Review, 1(1), 84-102.

Veloutsou, C., \& Guzman, F. (2017). The evolution of brand management thinking over the last 25 years as recorded in the Journal of Product and Brand Management. Journal of Product \& Brand Management, 26(1), 2-12.

Vieira, V. A., Sincorá, L. A., Pelissari, A. S., \& Carneiro, T. C. J. (2018). O Valor da Marca pela Perspectiva do Consumidor: Um Modelo Conceitual. Caderno Profissional de MarketingUNIMEP, 6(2), 125-139.

Wang, Y. H. (2017). Are Investors Willing to Buy Non-award-wining Funds from Awarded Fund Companies? Journal of Applied Finance and Banking, 7(1), 79.

Wu, S. I., \& Ho, L. P. (2014). The influence of perceived innovation and brand awareness on purchase intention of innovation product-an example of iPhone. International Journal of Innovation and Technology Management, 11(04), 1450026.

Xu, F., Li, Y., \& Zhou, J. (2015). Brand awareness for entrepreneurial hotel chains: Perceived quality and brand loyalty. The Anthropologist, 19(3), 763-771.

Yoo, B., \& Donthu, N. (2001). Developing and validating a multidimensional consumer-based brand equity scale. Journal of business research, 52(1), 1-14.

\section{ORIGEN OF THE ARTICLE}

This study is part of the master's dissertation carried out by the first author under the supervision of the second author in the Post-Graduate Business Administration Course. There is no conflict of interest in this article. 


\begin{tabular}{|c|c|}
\hline Variables & Itens \\
\hline \multirow{5}{*}{$\begin{array}{l}\text { Loyalty } \\
\text { (adapted from Yoo } \\
\text { \& Donthu, 2001) }\end{array}$} & LO01 - I consider myself to be loyal to this brand. \\
\hline & LO02 - This brand would be my first choice. \\
\hline & LO03 - I will not buy other brands if this brand is available. \\
\hline & LO04 - I am willing to pay a higher price for this brand compared to others. \\
\hline & LO05 - I am committed to this brand. \\
\hline \multirow{5}{*}{$\begin{array}{l}\text { Perceived Quality } \\
\text { (adapted from Yoo } \\
\text { \& Donthu, 2001) }\end{array}$} & PQ01 - This brand is of high quality \\
\hline & PQ02 - The likely quality of this brand is extremely high. \\
\hline & PQ03 - The likelihood that this brand will fit my needs is very high. \\
\hline & PQ04 - The likelihood that this brand is reliable is very high. \\
\hline & PQ05 - This brand seems to me to be of very good quality. \\
\hline \multirow{5}{*}{$\begin{array}{l}\text { Brand Associations } \\
\text { (adapted from Yoo } \\
\text { \& Donthu, 2001) }\end{array}$} & AS01 - Some characteristics of this brand come to my mind. \\
\hline & AS02 - I can quickly remember the symbol or logo of this brand. \\
\hline & AS03 - I can easily imagine this brand in my head. \\
\hline & AS04 - I have strong associations with this brand. \\
\hline & AS05 - I have favorable associations for this brand. \\
\hline \multirow{5}{*}{$\begin{array}{l}\text { Brand Awareness } \\
\text { (adapted from Yoo } \\
\text { \& Donthu, 2001; } \\
\text { Shah, 2012) }\end{array}$} & AW01 - I understand the meaning of this brand. \\
\hline & AW02 - I can identify this brand among competitors. \\
\hline & AW03 - I have knowledge about this brand. \\
\hline & AW04 - I am quite familiar with this brand. \\
\hline & AW05 - I believe most people know this brand. \\
\hline \multirow{5}{*}{$\begin{array}{l}\text { Purchase Intention } \\
\text { (adapted from Baker } \\
\text { \& Churchill, 1977; } \\
\text { Grewal et al., 1998) }\end{array}$} & PI01 - I would like to try this brand more often. \\
\hline & PI02 - I would buy from this brand if I saw it in a store / website. \\
\hline & PI03 - I would actively look for this brand. \\
\hline & PI04 - I am likely to buy this brand more often. \\
\hline & PI05 - I want to buy smartphones of this brand. \\
\hline
\end{tabular}

Source: Authors' own elaboration. 